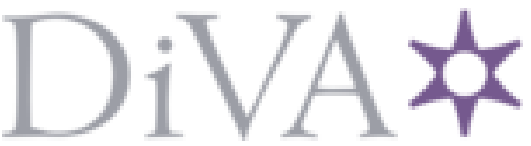

http://www.diva-portal.org

Preprint

This is the submitted version of a paper presented at Academy of Management (AOM) Meeting.

Citation for the original published paper:

Stål, H. (2017)

Institutional maintenance within the regulative pillar

In: Academy of Management Proceedings (pp. 15180-). Briarcliff Manor, NY 10510

N.B. When citing this work, cite the original published paper.

Permanent link to this version:

http://urn.kb.se/resolve?urn=urn:nbn:se:umu:diva-157807 


\title{
INSTITUTIONAL MAINTENANCE WITHIN THE REGULATIVE PILLAR
}

\author{
HERMAN STÅL \\ Umea School of Business and Economics (USBE), Sweden \\ herman.stal@umu.se
}

\begin{abstract}
There is a gap in the institutional work-literature regarding the role of the so-called regulative pillar for institutional maintenance. Understanding processes and outcomes related to this pillar are important, as they often have decisive impacts on the institutional dynamics within fields. To fill this gap, this paper draws on a case study of Swedish agri-food policy addressing climate change. By focusing on problematizations as triggers, the paper shows that policies supporting controversial practices are maintained as a redefined script that restores cognitive order is created. These case findings are then used to suggest several proposition regarding the characteristics of maintenance within the regulative pillar.
\end{abstract}

Keywords: institutional work, institutional maintenance, regulative pillar, problematization, climate change 


\section{INTRODUCTION}

The state and its regulatory action can have a strong influence on organizational practice (Campbell, 2007), yet the so-called "regulative pillar", remains the least understood within organizational institutionalism (Scott, 2008). In particular, little is known about the dynamics within this pillar (Peton \& Pezé, 2014), for instance how institutional work maintains policy support for criticized and controversial practices.

The institutional work literature has begun to uncover the work associated with maintenance (Currie, Lockett, Finn, Martin \& Waring, 2012; Dacin, Munir \& Tracey, 2010; Lawrence \& Suddaby, 2006; Lok \& Rond, 2012; Micelotta \& Washington, 2013) as it "involves supporting, repairing and recreating the social mechanisms that ensure compliance" (Lawrence \& Suddaby, 2006, p. 230). These mechanisms are usually categorized as cognitive, normative or regulative pillars, that support institutionalized practices (Scott, 2008).

Previously the institutional maintenance-literature has explored maintenance in relation to the normative- (Currie et al., 2012; Micelotta \& Washington, 2013) or cognitive pillar (Gawer \& Phillips, 2013), but, as mentioned, a gap remains considering maintenance involving the regulative pillar. In fact, this type of maintenance remains to be conceptually clarified, as it may refer to two different types of works: on the one hand the establishment of rules and on the other the enforcement of them. While Lawrence and Suddaby (2006) refers to the latter form of work, this paper argues that the former type, which looks to maintenance work "within" the regulative pillar, is of equal interest. Hence, this paper asks: How does institutional maintenance occur within the regulative pillar?

To clarify how the regulative pillar relates to organizational practice, this paper focuses on "policy", often broadly defined as the course of action governmental actors take to influence and intentionally guide others, for instance firms. Policy may refer to an object or a process, often depending on the purpose of a particular analysis (Heclo, 1972). Given this paper's 
purpose, policies are understood as objects, or more precisely rules, that describe how state organizations attempt to influence practice (cf, Jiao \& Boons, 2013). By focusing on how and why policies are kept or reinforced, maintenance work within the regulative pillar can be theorized. And when supporting policies are kept in place, they increase the likeliness that the business practices that are supported by the policies are maintained as well.

To understand how policies are preserved, despite wide-spread critique of the practices that they support, the paper relies on a case study from Swedish agri-food, where certain business practices, e.g., life stock farming, excessive fertilization and cultivation of organogenic soils constitute important sources of greenhouse gas-emissions, causing climate change (Swedish Board of Agriculture [SBA], 2008). The case studies explores state action concerning what (or whether) new policies were needed in order to influence agricultural practices to emit less greenhouse gases.

The paper makes the following contributions: It contributes to the institutional work-literature by conceptualizing and exemplifying institutional maintenance work within the regulative pillar. Through this account, it adds to this literature by describing the role of problematizations as triggers for maintenance work. Lastly, the paper also contributes theoretically through a number of theoretical propositions regarding the characteristics of maintenance within the regulative pillar.

\section{INSTITUTIONAL MAINTENANCE}

Institutions refer to combined elements that provide stability and meaning to social life, (Scott, 2001). Of particular relevance for this paper are institutionalized practices, consisting of "activity patterns across actors that are infused with broader meaning" (Lounsbury \& Crumley, 2007, p. 995). Hence, common business practice, underpinned by various industrywide understandings and norms, and supported by policies, serves as one example of an 
institution. While organizational institutionalism has elaborated on the role and constitution of institutions and how they diffuse among organizations (DiMaggio and Powell, 1983; Meyer and Rowan, 1977), Lawrence and Suddaby (2006, p. 215) offered a new perspective to institutional theory, when they defined "institutional work" as "the purposive action of individuals and organizations aimed at creating, maintaining and disrupting institutions".

The institutional work-perspective introduces at least three important aspects to institutional theory: First, by defining the object of study as "the purposive action", it stresses the importance of agency (Emirbayer \& Mische, 1998). Hence, actors are described as creative and reflective rather than cultural dopes that blindly follow taken-for-granted scripts (Lawrence \& Suddaby, 2006). On the other hand they are understood as boundedly rational, far from the strategic heroes implied by the reference to institutional entrepreneurship (Hardy \& Maguire, 2008). Second, the direction of causal interest is reversed. While neoinstitutionalist were interested in the effects of institutions (DiMaggio \& Powell, 1983; Meyer \& Rowan, 1977), institutional work looks to the effects of action on institutions (Lawrence et al., 2011). However, the third aspect, the reintroduction of action to maintain institutions (Currie et al., 2012; Micelotta \& Washington, 2013), is the most relevant to this paper.

Originally institutions were depicted as maintained automatically, rather than through purposive and skilled action (Jepperson, 1991). However, empirical studies revealing the “institutional wars" going on in many organizational fields (Hoffman, 1999), or co-existence of competing institutional logics (Reay \& Hinings, 2009), testify to the purposive action invested in defending and diverting attacks on the legitimacy of institutions (Maguire \& Hardy, 2009). Probably very few institutions have such powerful reproduction mechanisms that no purposive action is needed for maintenance (Lawrence \& Suddaby, 2006). Several researchers have shown that particularly environmental issues regularly introduce challenges to industrial practices which, in turn, spur activities by incumbents to re-legitimize and defend 
them (cf. Zietsma \& Lawrence, 2010). Environmental issues introduce arguments and ideas backed from an alternative institutional context (Harmon, Green \& Goodnight, 2015), such as the body of knowledge describing the unfolding of global climate change, thus challenging the dominance of the market based-rhetoric that reigns in industrial contexts. It is not uncommon for a practice to be commercially successful but catastrophic in terms of its effects on the biosphere (Maguire \& Hardy, 2009). In Hoffman's (1999) description of the US chemical industry, new regulation enable the battle to be fought in courts, while Maguire and Hardy (2009) describe how popular and scientific discourse was used to fight as well as defend DDT-use. Associated with climate change, there are many descriptions, both by researchers (Oreskes \& Conway, 2010) and journalists (Hoggan, Littlemore \& Ball, 2009), of how vested interests have, succeeded in defending the legitimacy of their practices in many arenas despite overwhelming scientific consensus (Lefsrud \& Meyer, 2012; Oreskes, 2004).

\section{Pillars and institutionalized practices}

To understand institutional maintenance, this paper focuses on the mechanisms that underpin institutionalized practices. These are often metaphorically categorized as regulative, normative and cognitive "pillars" (Scott, 2008). These pillars contain the different supports, and the actors connected with them, that sustain practices (Ahmadjian \& Robinson, 2001).

Somewhat simplistically, when pillars are in place, or not in conflict, practice persistence is to be expected and there is alignment between broad constituencies of actors in terms of how things are and should be. For instance, when professions and the associations that safeguard norms lose relative power, attempts at institutional change may follow (Greenwood \& Suddaby, 2006). In Maguire and Hardy's (2009) account of deinstitutionalization of DDT, normative and cognitive pillars are weakened, leading to a drop in DDT-use and ultimately a regulatory ban, while Hoffman (1999) describes how institutional change occurs first in the regulative pillar, and then, because of persistent legal battles, spread to the normative and 
cognitive ones. Hence, although the regulative pillar performs different roles in change processes, it may be particularly important for introducing more radical changes that in turn effect other pillars. Of course change need not follow, as Micelotta and Washington (2013) show in an account of how the normative pillar, through professions, manage to resist regulatory pressures. However the point is that change within the regulative pillar has at least a strong potential deinstitutionalizing effect that could be particularly relevant for challenging prevailing practices (Rainelli Weiss \& Huault, 2016).

Before moving on to elaborate on what the regulative pillar refers to, to compare and contrast, the other two pillars are here shortly described. First, the cognitive pillar refers to taken-forgranted cultural frames, part of the prevailing orthodoxy, which confers legitimacy to aligned practices (Scott, 2001). Important activities within this pillar concerns fact-making, such as establishing or disrupting scientific bodies of knowledge, that may shake or recreate frames that prevail within an industry (Maguire \& Hardy, 2009). Second, the normative pillar describes how notions of appropriateness supports practices (e.g., Ahmadjian \& Robinson, 2001). Professions are important actors in upholding and shaping the normative pillar, socializing new members into the values and moral obligations that accompany a profession and its practices (Scott, 2008).

The regulative pillar. As mentioned, the regulative pillar is the least understood or explored within institutional theory in general rendering previous definitions somewhat vague (Peton \& Pezé, 2014; Scott, 2008). Somewhat simplistically this pillar refers to the creation and enactment of regulation, and the influence of the state and its organizations. Regulation represents a specific type of rules, since the state has, in most contemporary societies, the unique right to coercively enforce its rules upon organizations (DiMaggio \& Powell, 1983). Thus regulation can effectively work to maintain certain business practices if competing ones 
are illegal and thus punished. The law also has a strong normative effect, in terms of suggesting what is appropriate in a particular society, at a particular point in time.

However, this understanding of how the state effects organizational practice is very limited, and ignores the wide arrange of techniques that state organizations use to influence others. Within political science, the variety of techniques is often discussed by referring to different types of "policy instruments" that can be categorized in relation to how coercive they are (Jordan, Wurzel, \& Zito, 2013, 2003). Organizational institutionalists have usually understood influence in terms of "command-and-control" (DiMaggio \& Powell, 1983) but policies also come in the form of financial incentives, market-based instruments and voluntary agreements etcetera. Typically contemporary states offer a range of financial subsidies, or tax breaks for some practices, while others are financially penalized. Thus beyond the fact that the regulative pillar is more dynamic than often suggested within institutional theory (Peton \& Pezé, 2014), it also has more diverse ways of influencing practices than usually envisioned.

Policy and maintenance. As mentioned, to unpack this impact, this paper focuses on the use of policies to conceptualize maintenance work. Understanding policies as rules that specify how different practices are influenced clarifies that maintenance work relates to two different functions, on the one hand the work going into the design and choice of policy, and on the other hand the work involved in enforcing policies once they are in place. Perhaps due to organizational institutionalism's lack of understanding of how the regulative pillar works, these two types tend to be blurred. They can be separated by conceptualizing the first type as institutional maintenance "within" the regulative pillar (keeping the policies supporting certain practices intact), and the latter as maintenance "from" the regulative pillar (making sure that rules are followed by organizations). Hence, this paper defines maintenance within the regulative pillar as work aiming to sustain policies that in turn support institutionalized practices. So purposive efforts at keeping policies that either reward certain practices or 
punish alternatives exemplifies this type of work. Arguably, ensuring compliance to rule systems, e.g., through monitoring or evaluation, is less of the creative and reflective action suggested by the institutional work-concept than efforts to devise or defend the rules themselves.

To further analyze this work within the regulative pillar we understand policies as consisting of outlined "means" and "ends", where the latter refers to the specific effect on practices that is intended, while means refers to the particular policy instrument employed to achieve that effect. So for instance if a policy is intended to increase investments in renewable energies (ends) it will use different techniques (means) such as investment supports, tax breaks or information campaigns to achieve this result.

\section{Problematizations as triggers}

To conceptualize the elements of maintenance, this paper draws inspiration from Maguire and Hardy (2009), and their emphasis upon “problematizations” as triggers for institutional work.

Problematizations denote claims, statements, ideas and arguments and were originally described to "substantiate and dramatize the ineffectiveness and injustice of existing practice" (Colomy, 1998, p. 298). However, problematizations that are less dramatic, but substantiated by the legitimacy of well-positioned actors, may be just as effective. Hence, the assumption that rhetorical strategies are always used to make problematizations more persuasive to their audiences should be relaxed. Although the possibility of embedded agency may exist (Battilana, Leca \& Boxenbaum, 2009; Garud, Hardy \& Maguire, 2007; Greenwood \& Suddaby, 2006; Holm, 1995), problematizations often originate from outside fields (Maguire \& Hardy, 2009), and alternative institutional contexts (Harmon et al., 2015), exemplified in this paper by the global climate change-regime (Lefsrud \& Meyer, 2012). Problematizations suggest alternative, negative, meanings of practices, calling attention to the problems they 
cause (Maguire \& Hardy, 2009). Thus when the purpose is to maintain supporting policies, problematizations function as "triggers", spurring reflective and creative work.

Previous accounts of institutional maintenance have focused on other types of triggers: Lok and Rond (2012) discuss how unsystematic practice variation induce stretching of cognitive and normative scripts to avoid change, showing how institutions that appear remarkable stable are in fact accompanied by deviations that need to be handled through maintenance. Micelotta and Washington (2013), in turn, discuss how actions from other pillars (the regulative), in the form of chocks, trigger maintenance labeled as "repair work". These examples may indicate that there is a relation between the type of trigger and the type of pillar involved. State organizations may be particular responsive to problematizations, especially of a less dramatic kind, but it may of course depend on what type of state actors that are involved and what a legitimate argument and process consist of within that setting. For example, within the state bureaucracies explored in this paper decision processes are highly rationalistic, referring to means, ends, evaluations and measurements (Brunsson, 2006). Moreover, triggers are likely to be different if maintenance within or from pillars are focused, in the latter case the typical trigger would consist of a breach of a rule of some kind. None-the-less, this makes it relevant to gather multiple descriptions of institutional maintenance as descriptions may be distinct and operate according to specific contextual and theoretical mechanisms.

Below Fig. 1 summarizes how the paper situates maintenance work triggered by problematizations within the regulative pillar, which then, through policy supports relate to institutionalized practices.

\section{FIGURE 1}

\section{Maintenance within the regulative pillar}

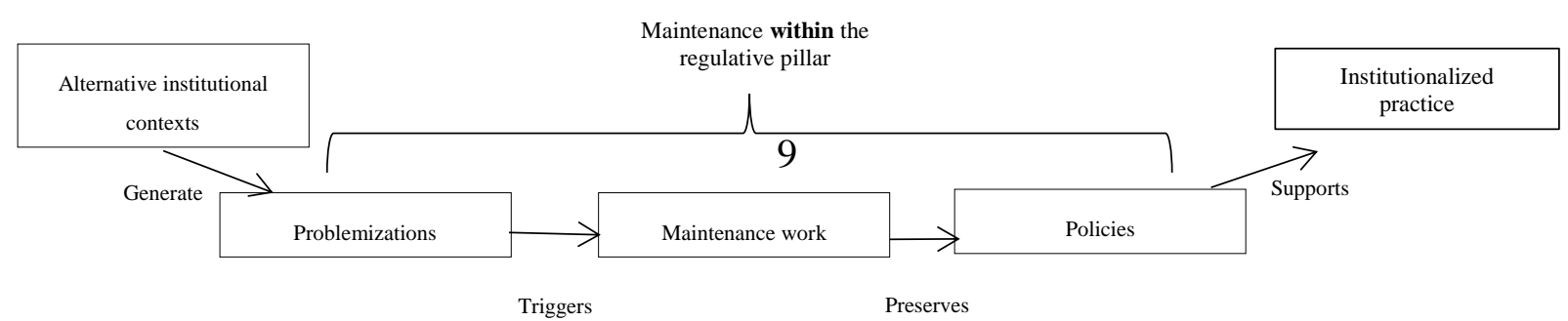




\section{METHODOLOGY}

As indicated, this paper utilized a case study-methodology, which fits the purpose to develop and extend, rather than to test propositions within, the maintenance-literature (Eisenhardt \& Graebner, 2007; Siggelkow, 2007). Swedish agri-food and climate change was chosen as a relevant context, given the influence that the regulative pillar has on the industry and the way climate change problematized agri-food practices (Smith et al., 2007). The state organizations responsible for agriculture and agricultural policy aims to influence, via multiple policies including environmental and animal-safety laws, specific and general financial supports and provision of advice and information, farmers' practices (farmers receive on average twothirds of their incomes from the state). Hence, what happens within the regulative pillar may be particularly decisive to sustain or change agricultural practice.

When it comes to climate change, agricultural practice, involving crop cultivation and animal husbandry, has a major impact on climate change, constituting between 10-12\% of global emissions, but when land-use is included they account for $24 \%$ of emissions. By far the largest single source is that of "enteric fermentation", methane emitted as cattle (cows and bulls) burp and fart during their digestion (Smith et al., 2014). In fact, agri-food is so important that the IPCC-report on mitigation devotes a whole single chapter to it (Smith et al., 2014).

In Sweden, the sector currently accounts for $10 \%$ of greenhouse gas-emissions, but these emissions are difficult to address as there is a lack of technical solutions, there are no carbonfree processes of producing meat or crops at present (SBA, 2013). Sweden seemed a relevant case context as the agri-food industry, and policy, puts relative large emphasis upon agrienvironmental issues, thus the problematizations mentioned above would not go unnoticed (Author, 2011). Claims and facts regarding the greenhouse gas-intensity of Swedish agri-food 
practices received much media attention and spurred considerable debate, and therefore could not be ignored by policy makers and state agencies.

Altogether this made Swedish agri-food a promising empirical setting to explore the paper's research question, as climate change appeared to suggest regulatory change. At the same time agri-policy also aims to protect the competiveness of the industry. Subsequently, a dynamic and reflective process, within the regulative pillar, that would effectively exemplify maintenance work, could be expected.

In choosing a case, we looked for as demarcated state projects, clearly shaping the policies that addressed agri-food's emissions of greenhouse gases. Thus, projects had to produce some type of policy outcome. Hence, projects, and there were several, that were predominantly about research and mapping out problems, were excluded.

Two suiting initiatives indicated the relevance of the governmental bureau responsible for agri-food - the Swedish Board of Agriculture (SBA). SBA investigates and suggests policy concerning agri-environmental issues but its overarching purpose is to enhance the competiveness of the Swedish industry. SBA acts as an expert authority, called upon whenever debate and media attention is induced by new issues that seemingly problematize the status quo. In Sweden such issues may include economic well-being of farmers, animal welfare, pesticide-use, eutrophication of lakes and rivers and climate change. In response to such debate, the Agricultural Ministry will most often order SBA to conduct an investigation and suggest policy, which thus functions as a way to handle and adjudicate between competing claims.

\section{The Action Plan-project - SBA investigation}

When greenhouse gas-reduction climbed the agenda in 2007, following the release of the fourth IPCC-report (IPCC, 2007) and a stream of bestselling books (Friedman, 2008, Gore, 
2006, Lynas, 2007), it was new to the Swedish policy debate. The government ordered all its bureaus, including SBA, to perform investigations to suggest how emissions could be reduced. SBA was asked to suggest an Action Plan that should entail policy to implement them (Swedish Ministry of Agriculture, 2008). SBA put together a project consisting of a group of SBA investigators supported by an advisory board, consisting of leading agricultural researchers and other bureau and industry representatives. In total the Action Plan-project gathered 15 people that all were experts on agricultural policy, farming and agri-

environmental issues. The project ran from late 2008 until its deadline in April $30^{\text {th }} 2010$, when the suggestion was handed to the government (see SBA, 2010a).

\section{Greppa Näringen - provision of climate advice.}

In parallel to the project, a group of experienced advisors within SBA's agricultural extension service "Greppa Näringen" (GN), had started to develop advice on how farmers could reduce their greenhouse gas-emissions. GN's purpose is to develop and administer packages of advice, targeting for instance fertilization, pesticide use, land drainage, wetlands, then made available to farmers for free, through the services of private consultants. Independent contractors (consultants) visit the farm where they advise farmers. The first round of 34 consultants were certified and started to provide climate advice in 2010.

\section{Data collection and analysis}

Qualitative methods were used to collect data in both case studies. The aim was interview all those participating in the Action Plan-project, both from SBA and the advisory board. Among these 15 , two declined to participate referring to their workload, despite several probes. In addition, SBA's chief economist, a representative of Swedish Society for Nature Conservation (leading Swedish environmental NGO), and other SBA-, Ministry- and bureau staff were also interviewed. For the GN-study all 34 consultants were contacted through e-mail, however 7 never returned the e-mail despite several reminders, and 6 declined to participate stating that 
they had provide none, or next to none, climate advice. Out of the remaining 19, 15 were interviewed once and 4 were also interviewed a second time before accompanying them to farm visits (see Table 2).

The amount of provided climate advice differed among the consultants, where three of the interviewed consultants (that all operated their own, small firms), stood out in terms of having conducted from 40 to over a 100 visits. Two of these were interviewed twice and accompanied to visits. Likewise, the two Action Plan-project leaders investigated more of the problematizations, and wrote more of the final report. Although their accounts may affect the data material more, this is reasonable since they also had a larger effect on both outcomes and activities.

TABLE 1

Respondents

\begin{tabular}{|c|c|c|c|}
\hline Respondent & Type of interview ${ }^{a}$ & $\begin{array}{l}\begin{array}{l}\text { Organizational } \\
\text { role/background }\end{array} \\
\end{array}$ & Comments \\
\hline \multicolumn{4}{|l|}{ AP-project: } \\
\hline $\begin{array}{l}\text { SBA investigator/AP } \\
\text { manager (1) }\end{array}$ & $\begin{array}{l}\text { Meeting/interviewed } \\
\text { twice }\end{array}$ & SBA staff & Central role \\
\hline $\begin{array}{l}\text { SBA investigator/AP } \\
\text { manager (2) }\end{array}$ & $\begin{array}{l}\text { Phone/interviewed } \\
\text { twice }\end{array}$ & SBA staff & Central role \\
\hline SBA investigator (3) & Phone & SBA staff & $\begin{array}{l}\text { Investigated carbon } \\
\text { storage in land for } \\
\text { grazing }\end{array}$ \\
\hline SBA investigator (4) & Phone & SBA staff & \\
\hline SBA investigator (5) & Phone & SBA staff & \\
\hline SBA manager (6) & Phone & Manager & Had a supervisory role \\
\hline SBA manager (7) & Phone & Manager & Had a supervisory role \\
\hline $\begin{array}{l}\text { SBA investigator/GN } \\
\text { manager (8) }\end{array}$ & Meeting & $\begin{array}{l}\text { Project staff/GN } \\
\text { consultant }\end{array}$ & $\begin{array}{l}\text { Somewhat involved in } \\
\text { both initiatives }\end{array}$ \\
\hline Researcher (9) & Phone & $\begin{array}{l}\text { Advisory board } \\
\text { representative }\end{array}$ & $\begin{array}{l}\text { Lund University } \\
\text { researcher on } \\
\text { bioenergy production }\end{array}$ \\
\hline Researcher (10) & Phone & $\begin{array}{l}\text { Advisory board } \\
\text { representative }\end{array}$ & $\begin{array}{l}\text { Expert on organogenic } \\
\text { soils - contested the } \\
\text { idea of changing } \\
\text { cultivation of } \\
\text { organogenic soils }\end{array}$ \\
\hline Researcher (11) & Phone & $\begin{array}{l}\text { Advisory board } \\
\text { representative }\end{array}$ & $\begin{array}{l}\text { Expert on cattle } \\
\text { emissions }\end{array}$ \\
\hline $\begin{array}{l}\text { Bureau representative } \\
\text { (12) }\end{array}$ & Phone & $\begin{array}{l}\text { Advisory board } \\
\text { representative }\end{array}$ & $\begin{array}{l}\text { Swedish } \\
\text { Environmental } \\
\text { Protection Bureau }\end{array}$ \\
\hline
\end{tabular}




\begin{tabular}{|c|c|c|c|}
\hline $\begin{array}{l}\text { Industry representative } \\
\text { (13) }\end{array}$ & Phone & $\begin{array}{l}\text { Advisory board } \\
\text { representative }\end{array}$ & $\begin{array}{l}\text { Federation of Swedish } \\
\text { farmers-representative } \\
\text { - expert on greenhouse } \\
\text { gas-emissions }\end{array}$ \\
\hline $\begin{array}{l}\text { SBA chief economist } \\
\text { (14) }\end{array}$ & Phone & Supervisory role & $\begin{array}{l}\text { Conducted a "quality" } \\
\text { check of the final } \\
\text { report }\end{array}$ \\
\hline $\begin{array}{l}\text { Ministry of } \\
\text { Agriculture staff (15) }\end{array}$ & Phone & $\begin{array}{l}\text { Contact between SBA } \\
\text { and the ministers }\end{array}$ & \\
\hline GN-manager (16) & Meeting & SBA/GN & $\begin{array}{l}\text { Somewhat involved in } \\
\text { both initiatives }\end{array}$ \\
\hline $\begin{array}{l}\text { Section manager SBA } \\
\text { (17) }\end{array}$ & Phone & $\begin{array}{l}\text { Chair of the Advisory } \\
\text { Board meetings }\end{array}$ & \\
\hline $\begin{array}{l}\text { NGO agricultural } \\
\text { expert (18) }\end{array}$ & Meeting & $\begin{array}{l}\text { Swedish Society for } \\
\text { Nature Conservation }\end{array}$ & $\begin{array}{l}\text { Not part of the } \\
\text { advisory board but } \\
\text { commented on the } \\
\text { final report (late } \\
\text { referral round) }\end{array}$ \\
\hline \multicolumn{4}{|l|}{$\begin{array}{l}\text { GN-provision of } \\
\text { climate advice: }\end{array}$} \\
\hline GN manager (16) & Meeting & SBA/GN & $\begin{array}{l}\text { Somewhat involved in } \\
\text { both initiatives }\end{array}$ \\
\hline $\begin{array}{l}\text { SBA investigator/GN } \\
\text { manager }(8)\end{array}$ & Meeting & $\begin{array}{l}\text { Project staff/GN } \\
\text { consultant }\end{array}$ & Developed the module \\
\hline Consultant (19/CÅ) & Phone \& meeting & Råby konsult (own) ${ }^{\mathrm{b}}$ & $>100$ farm visits \\
\hline Consultant (20/ED) & Phone \& meeting & $\begin{array}{l}\text { Vestgöte Dreber Gård } \\
\text { \& Konsult (own) }\end{array}$ & $\sim 40$ \\
\hline Consultant (21/BN) & Phone & Mulekonsult (own) $)^{\mathrm{b}}$ & $\sim 70$ \\
\hline Consultant (22/CaP) & Phone & Växtråd & $\sim 15$ \\
\hline Consultant (23/AE) & Phone \& meeting & $\begin{array}{l}\text { Swedish Rural } \\
\text { Economy and } \\
\text { Agricultural Societies }\end{array}$ & $\sim 20$ \\
\hline Consultant (24/EH) & Phone & $\begin{array}{l}\text { Swedish Rural } \\
\text { Economy and } \\
\text { Agricultural Societies }\end{array}$ & $\sim 3$ \\
\hline Consultant (25/MiB) & Phone & $\begin{array}{l}\text { Swedish Rural } \\
\text { Economy and } \\
\text { Agricultural Societies }\end{array}$ & N/A \\
\hline Consultant (26/JH) & Phone & $\begin{array}{l}\text { Swedish Rural } \\
\text { Economy and } \\
\text { Agricultural Societies }\end{array}$ & $\sim 20$ \\
\hline Consultant (27/KB) & Phone \& meeting & Rådgivarna & 2 \\
\hline Consultant (28/KE) & Phone & Rådgivarna & 5 \\
\hline Consultant (29/MB) & Phone & Växa Sverige & N/A \\
\hline Consultant (30/CC) & Phone & Växa Halland & Developed the module \\
\hline Consultant (31/CP) & Phone & Växa Gotland & $\sim 12$ \\
\hline Consultant (32/IL) & Phone & Skåne semin & 2 \\
\hline Consultant (33/MW) & Phone & Skåne semin & 4 \\
\hline Consultant (34/SR) & Phone & Skåne semin & $4-5$ \\
\hline Consultant (35/MD) & Phone & Skåne semin & 1 \\
\hline Consultant $(36 / \mathrm{CH})$ & Phone & LG Husdjurstjänst & N/A \\
\hline Consultant (37/PN) & Phone & LRF Konsult & $\sim 15$ \\
\hline Farmer (38/M) & Observation & Lilla Edet & With KB (27) \\
\hline Farmer (39/MA) & Observation & Långelycke & With CÅ (19) \\
\hline Farmers (40/A \& B) & Observation & Fillinge mellangård & With ED (20) \\
\hline
\end{tabular}




\begin{tabular}{llll}
\hline Farmer (41/CO) & Observation & COGO AB & With ED (20) \\
Farmer (42/GM) & Observation & GM Farming AB & With AE (23) \\
Group meeting & Observation & $\sim 10$ farmers & With CÅ (19) \\
\hline
\end{tabular}

anterviews were carried out over the phone to accommodate time-pressed respondents but also to cut down on unnecessary travel, despite potentially missing out on non-verbal ques.

${ }^{\mathrm{b}}$ These consultants are self-employed and have specialized in $\mathrm{GN}$-advice, while larger firms also provide production and economic advice.

We asked for accounts of agri-food emissions (problematizations), and reflections regarding the type of policies these should induce, and how such policies were discussed, evaluated and presented. Interviews (all but three) were taped and fully transcribed. To verify accounts, the researcher participated in five farm visits and one meeting where a consultant spoke to a group of farmers.

The interview data and the final Action Plan-report was first coded according to the particular problematization being investigated or discussed (although it was sometimes difficult to separate quotes regarding problems from those that focusing on policies). For each problematization it was noted what suggestions of policy (means and ends) that were related, and what agri-food practices these related to. For instance, management of ruminant cattle (practice) was discussed due to greenhouse gas-emissions from animals' digestion systems or the handling of manure (problematization) with ideas of increasing fodder efficiency (end), and thus interview statements that dealt with these issues were grouped in a theme. As a result of this analysis it could be established that institutional maintenance was in fact an outcome (few policies aiming to change practice were suggested). Moreover, a set of micro-processes could be modeled, describing how problematizations were handled, making up the various facets of the institutional maintenance taking place. From the analysis of these microprocesses a series of unified second order-themes could be categorized, which suggested reoccurring patterns across the micro-processes. These three second-order themes where then further abstracted in to a set of higher order themes, describing the general elements of institutional maintenance within the regulative pillar. 


\section{FINDINGS}

The first part of the findings describe the problematizations and the policies discussed and suggested by the SBA, thus pointing to the conclusion that maintenance was in fact taking place within the regulative pillar.

\section{Problematizations and policies}

In 2008, just before the Action Plan-project began, SBA published a report interpreting what greenhouse-gas reduction meant within the Swedish agri-food industry, identifying the major emission sources (SBA, 2008; see Table 2). The report also linked these problematizations to existing agri-food practice, hinting at possible changes. Although conveyed in a neutral language, serious problematizations surfaced, and depending on what policies that were taken, it seemed to suggest that the regulative support for certain practices was serious jeopardy. The threat was perhaps most serious for cattle farmers, since they are currently provided large state support (for biodiversity reasons) and at the same time cause large greenhouse gasemission:

We pay out 700-800 million SEK annually for the keeping of natural grasslands [...]. In the societal debate, the climate issue is huge and this permeates politics too. It is at the moment much stronger than biodiversity - there is no question about it (SBA investigator (3)).

Removing these supports would seriously threaten this production as they they represent the largest part of more or less terminate this production as it represents the major part of these farmers' income. But crop cultivators utilizing organogenic soils also had reasons for worry, as the report discussed a ban against the current use of these carbon rich soils:

They [farmers] do not want a ban put upon this production (Industry representative (13)). 
Action Plan-project's policy. In the project 12 different policies were mentioned as potential ways to reduce emissions, some dismissed early on while others ended up as suggestions in the final report. Table 2 shortly describes the different ends that were discussed, their relation to problematizations, and the different aspects of agricultural practice that these ends, if implemented, would affect. Thus the fifth column shows that, despite problematizations, the pillar's support for industrial practice was recreated. Of the ends decreased output (B) was never really discussed as an alternative, but was still repeatedly mentioned by the respondents as theoretically the quickest way to reduce Swedish emissions.

The Action Plan's main conclusion was that it was harder to reduce greenhouse gas-emissions in agri-food than in other industries. For that reason the overarching suggestion was to increase production of bioenergy to replace the use of fossil fuels in other sectors, rather than to change agri-food practice. In other words, few policies to change practices were suggested, and support from the regulative pillar remained. In some cases this meant that financial supports that subsidize greenhouse gas-intense practices, such as those to beef farmers, were kept $(E, G)$. In other cases it meant that new policies that could challenge practice were dropped (E).

GN's policy. In the terminology of SBA, the climate advice provided through GN functions as a policy instrument, relying on information and education to alter farmers' practice. Hence, certain policy ends described in Table 2 were part of consultants' climate advice. However, measures dealing with renewable energy (I-J) were not included in the advice, and neither were A-C and K. A-C were not included since these measures were dismissed by the Action Plan-project and K was not included because GN already provided advice that dealt specifically with this.

- $\quad$ Insert table 2 here - 


\section{TABLE 2}

\section{Policies discussed*}

\begin{tabular}{|c|c|c|c|c|c|}
\hline Problematization & $\begin{array}{l}\text { Policies } \\
\text { discussed }\end{array}$ & Description & $\begin{array}{l}\text { Action Plan- } \\
\text { project }\end{array}$ & GN & $\begin{array}{l}\text { Potential effect on the regulative } \\
\text { support for practice }\end{array}$ \\
\hline $\begin{array}{l}\mathrm{CH}_{4} \text {-emissions from } \\
\text { ruminant cattle. }\end{array}$ & $\begin{array}{l}\text { A Carbon } \\
\text { storage in } \\
\text { farm land }\end{array}$ & $\begin{array}{l}\text { Grassland used for grazing could } \\
\text { perhaps function as carbon sinks } \\
\text { and capture carbon from the } \\
\text { atmosphere. }\end{array}$ & $\begin{array}{l}\text { Investigated but } \\
\text { dismissed }\end{array}$ & $\begin{array}{l}\text { Not } \\
\text { included. }\end{array}$ & $\begin{array}{l}\text { Would provide an argument for } \\
\text { continued policy support for beef } \\
\text { farming. }\end{array}$ \\
\hline $\begin{array}{l}\mathrm{CH}_{4} \text {-emissions from } \\
\text { ruminant cattle; } \mathrm{N}_{2} \mathrm{O} \\
\text { from cultivated soils; } \\
\text { organogenic soils } \\
\text { emitting } \mathrm{CO}_{2} \text { and } \mathrm{N}_{2} \mathrm{O} \text {. }\end{array}$ & $\begin{array}{l}\text { B Decreased } \\
\text { output }\end{array}$ & $\begin{array}{l}\text { Decreasing the number of animals } \\
\text { or acres of cultivated land would } \\
\text { be the safest way to reduce } \\
\text { emissions but could also shift those } \\
\text { emissions to other countries if } \\
\text { food-imports compensate. }\end{array}$ & $\begin{array}{l}\text { Never investigated } \\
\text { but mentioned. }\end{array}$ & $\begin{array}{l}\text { Not } \\
\text { included. }\end{array}$ & $\begin{array}{l}\text { Would provide arguments for removing } \\
\text { many agricultural supports and } \\
\text { considerably weaken the regulative } \\
\text { pillar's support. }\end{array}$ \\
\hline $\begin{array}{l}\mathrm{N}_{2} \mathrm{O} \text { emissions and } \\
\text { energy-use concerning } \\
\text { synthetic fertilizer } \\
\text { production; } \mathrm{CO}_{2-} \\
\text { emissions caused by } \\
\text { deforestation linked to } \\
\text { production of soy. }\end{array}$ & $\begin{array}{l}\text { C Organic } \\
\text { farming }\end{array}$ & $\begin{array}{l}\text { Since organic farmers do not use } \mathrm{N} \\
\text { fertilizers this could reduce some } \\
\text { emissions. }\end{array}$ & $\begin{array}{l}\text { Dismissed early } \\
\text { on. }\end{array}$ & $\begin{array}{l}\text { Not } \\
\text { included. }\end{array}$ & $\begin{array}{l}\text { Would provide arguments for policy } \\
\text { support for organic farming and weaken } \\
\text { the regulatory support for conventional } \\
\text { practices. }\end{array}$ \\
\hline $\begin{array}{l}\mathrm{N}_{2} \mathrm{O} \text {-emissions from } \\
\text { cultivated soils. }\end{array}$ & $\begin{array}{l}\text { D Optimized } \\
\text { use of } \mathrm{N} \\
\text { fertilizers }\end{array}$ & $\begin{array}{l}\text { When there is excessive nitrogen in } \\
\text { the soils, this is lost as } \mathrm{N}_{2} \mathrm{O} \\
\text { emissions. }\end{array}$ & $\begin{array}{l}\text { Suggested to be } \\
\text { implemented } \\
\text { through GN. }\end{array}$ & $\begin{array}{l}\text { Included - } \\
\text { however } \\
\text { already } \\
\text { promoted } \\
\text { by GN. }\end{array}$ & $\begin{array}{l}\text { Since instruments were more or less } \\
\text { voluntary it does not really challenge } \\
\text { conventional cultivation practices. }\end{array}$ \\
\hline $\begin{array}{l}\text { Organogenic soils } \\
\text { emitting } \mathrm{CO}_{2} \text { and } \mathrm{N}_{2} \mathrm{O} \text {. }\end{array}$ & $\begin{array}{l}\text { E Changed } \\
\text { cultivation of } \\
\text { organogenic } \\
\text { soils }\end{array}$ & $\begin{array}{l}\text { Organogenic soils are particularly } \\
\text { carbon rich, former wetlands. } \\
\text { When cultivated the carbon is lost } \\
\text { as } \mathrm{CO}_{2} \text { emissions. }\end{array}$ & $\begin{array}{l}\text { Investigated but } \\
\text { dismissed. }\end{array}$ & $\begin{array}{l}\text { Mentioned } \\
\text { by some } \\
\text { consultants. }\end{array}$ & $\begin{array}{l}\text { Would signal that such soils should not } \\
\text { be used. Could include a ban against } \\
\text { certain cultivation. }\end{array}$ \\
\hline
\end{tabular}




$\mathrm{CO}_{2}$-emissions caused
by deforestation linked
to production of soy

to production of soy

$\mathrm{CH}_{4}$-emissions from ruminant cattle.

Electricity production causes small $\mathrm{CO}_{2-}$ emissions

Targets emissions in other industries.

\section{$\mathrm{CH}_{4}$ and $\mathrm{N}_{2} \mathrm{O}$}

emissions from farm yard manure

All cultivated soils emit some amount of $\mathrm{CO}_{2}$ as they are cultivated.

$\mathrm{N}_{2} \mathrm{O}$ emissions and energy-use concerning synthetic fertilizer production

\section{$\mathrm{F}$}

cement of imported

soy

$\mathrm{G}$ Changes in

the

production

meat and

milk

H Increased Farmers can do a lot of behavioral energy efficiency

I Production

of renewable energy

J Decaying of farm yard manure

K Reduced tillage

L Choice of $\mathrm{N}$ fertilizers leaks $\mathrm{N}_{2} \mathrm{O}$ emissions. There is large differences in how the fertilizers are produced and a certification might clarify this to the farmers. emissions.

More efficient production would of keeping the carbon stored in the cultivated land. energy- intense process that a very

\section{Investigated and \\ Mentioned \\ $\begin{array}{ll}\text { suggested through } & \text { by some } \\ \text { supports. } & \text { consultants. }\end{array}$ \\ Conventional dairy farming (organic \\ farmers do not use imported soy)}

Investigated and Included suggested through central supports.

\section{according}

to some

consultants.

$\begin{array}{ll}\text { Investigated and } & \text { Mentioned } \\ \text { suggested through } & \text { by some }\end{array}$ supports. consultants.

Investigated and Not suggested through included.

large financial

supports

Investigated and Not suggested through included.

large financial

supports.

Investigated and Not supported through included. specific training.

Discussed but not Included. suggested.

Since instruments were more or less voluntary it does not really challenge beef and dairy farming.

\section{No effects}

Does not challenge agri-food practices per se but supports the alternative of farmers producing energy instead of food.

Does not challenge agri-food practices per se but supports the alternative of farmers producing energy instead of food.

Supports tillage-free crop cultivation sing non-certified fertilizers.

*Adapted from (Author et al., 2015) 
Moreover, since the consultants have freedom to focus on different things, different consultants mentioned different policy ends, shaping policy as they go. Since two of the measures included, D and G, describe how farmers can become more efficient regarding inputs and animals, they were not only responses to problematizations related to climate. Optimizing the use of fertilizers (D) is linked to other environmental issues, and providing this type of advice is the reason that GN was started in the first place (farmers were perceived to be over-fertilizing causing eutrophication of lakes and rivers). Thus similar to the Action Plan-project, GN entailed little change in the regulative pillar, promoting familiar policy ends. Rather consultants focused on linking greenhouse gas-reduction to the notion of increasing overarching efficiency. Thus critique of contemporary practice was limited in the provision of advice.

\section{Unpacking of institutional maintenance}

As shown few forceful measures were suggested in response to problematizations, to explain this outcome, maintenance work, is described in Table 3 through first, second and third order themes that display how respondents restore the legitimacy of policies despite problematizations. First order themes describe a mix of empirical arguments used to frame respondents' understanding of the issue, often based on broader discourses of how the market works, the economic rationality of actors or natural science. In addition, although respondents are not farmers themselves, farmer interests are seemingly protected through a strong undercurrent of sympathy expressed throughout.

These different third-order themes can in turn be arranged into three different second-order themes that enable institutional workers to achieve two things: On the one hand to recognize the seriousness of climate change as an issue but still moderate the challenge to practice in this particular context, and on the other hand deny that it will mean any radical change in pre- 
existing policies (by problematizing ideas of new policies and shifting the blame to other actors).

So the problem as such (climate change) is not down-played, but its implications for agricultural practice is. This is because the source of the emissions is presented as less the result of what farmers do, and more the result of inevitable, biological, processes. Hence, an element of determinism is introduced, ultimately traced back to how the market works and what choices consumers make.

New ideas for policy are in turn stopped in the Action Plan as various stakeholders engage themselves in problematizing these ideas. Hence, the focus of problematizations" "move" from being directed at practice toward the policy ideas at remedying that practice.

Maintenance within the regulative pillar is achieved by safeguarding multiple criteria in terms of what effective policy should be, and carefully scrutinizing any new ideas.

In the GN example any policy push for practice change is rather moderated by the argument that the responsibility for change lays with other actors beside farmers. Thus GN consultants engage themselves in shaping who is responsible for taking action.

In addition, policy instruments that challenge industry interests are perceived as sensitive, in the case of the Action Plan-project this refers to the use of bans and prohibitions, in the case of GN consultancy it seems even more sensitive as anything that can be interpreted as verbal critique can be controversial. 
TABLE 3

\section{Unpacking institutional maintenance within the regulative pillar}

\begin{tabular}{|c|c|c|c|c|}
\hline Quotes & First order themes & Second order themes & Third order theme & $\begin{array}{l}\text { Effects within the } \\
\text { regulative pillar }\end{array}$ \\
\hline $\begin{array}{l}\text { Partly, it [these difficulties] stem from the fact that } \\
\text { there are complex biological processes behind these } \\
\text { GHG emissions from agriculture, particularly } \mathrm{N}_{2} \mathrm{O} \\
\text { and } \mathrm{CH}_{4}(\text { Consultant }(27)) \text {. }\end{array}$ & $\begin{array}{l}\text { Biological } \\
\text { complexity }\end{array}$ & $\begin{array}{l}\text { Neutralizing } \\
\text { problematizations - } \\
\text { GHG emissions from } \\
\text { agricultural practice } \\
\text { are presented as }\end{array}$ & $\begin{array}{l}\text { New script }- \text { efficient } \\
\text { practices are defined as } \\
\text { climate friendly. Since } \\
\text { Swedish farming, in } \\
\text { international }\end{array}$ & $\begin{array}{l}\text { Reorders cognitive } \\
\text { order - integrates } \\
\text { problematizations into a } \\
\text { redefined understanding } \\
\text { of practice and how it }\end{array}$ \\
\hline $\begin{array}{l}\text { The big problems with emissions from agriculture } \\
\text { is that they have a biological origin. Emissions have } \\
\text { a biological origin which makes them hard to } \\
\text { capture. It's different from fossil fuels where it is } \\
\text { easy to quantify the effects of a measure (SBA } \\
\text { investigator (2)). }\end{array}$ & & $\begin{array}{l}\text { inevitable, because of } \\
\text { biological and market } \\
\text { mechanisms. }\end{array}$ & $\begin{array}{l}\text { comparison, is perceived } \\
\text { as relative efficient } \\
\text { already, the issue of } \\
\text { climate change does not } \\
\text { threaten its legitimacy. }\end{array}$ & $\begin{array}{l}\text { relates to climate change } \\
\text { that provides continued } \\
\text { support for a policy that, } \\
\text { in turn, continues to } \\
\text { support Swedish agri- } \\
\text { food. }\end{array}$ \\
\hline $\begin{array}{l}\text { It is important to show that agriculture is special } \\
\text { compared with many other sectors; that it is much } \\
\text { more difficult and probably much more expensive } \\
\text { to reduce emissions in agriculture compared to } \\
\text { other sectors (SBA investigator/project manager } \\
\text { (1)). }\end{array}$ & & & $\begin{array}{l}\text { Farmers should strive } \\
\text { for efficiency, which is } \\
\text { beneficial for their firms } \\
\text { and viable despite } \\
\text { financial hardship. }\end{array}$ & \\
\hline \multicolumn{5}{|l|}{$\begin{array}{l}\text { My understanding is that there is not a lot that can } \\
\text { be changed, but of course there are things that each } \\
\text { individual farm and farmer can influence, on his } \\
\text { own farm - of course there are, but there is much } \\
\text { that we cannot influence (Consultant (33)). }\end{array}$} \\
\hline $\begin{array}{l}\text { These are extremely complex systems and soils } \\
\text { vary - in field alone it can vary a great deal. And } \\
\text { then one has looked at one type of soils only and is }\end{array}$ & & & & \\
\hline
\end{tabular}


then, all of a sudden, drawing conclusions about

Sweden's entire agriculture (Researcher (10)).

But it is also - you have to discuss more like: 'we

do actually want to eat beef and drink milk, so these

determinism

emissions have to exist'. So they should not take it

personally, that they are the worst villains. It just is

like it has to be (Consultant (25)).

But where I am working at the moment, there are a

lot of beef producers and they do not make ends

meet really. And that kind of brings an identity

crisis. What am I really working with? I am not

making any money and then I do not really have a

job. But they are working their fingers to the bone

for hours, still (Consultant (20)).

You cannot criticize the production in any way but

rather [have to] see its possibilities (Consultant

(20)).

Reluctance to

directly question

industrial practice

\section{regarding new policy \\ that challenge}

agricultural practice

I do not believe in moralizing. That does not work.

You have to have specific solutions for the specific farm because the farmer is under so much pressure that he has no time to sit down for a few hours and listen to me talk about how he is going to save the world. That will not work (Consultant (19)).

Yes, I have been to a farm where they thought that [my advice] put too much focus on the

environment. Where they thought

that... they cannot save the world and all that

(Consultant (23)). 
[...] if the SBA would make suggestions, for instance in this report, that would mean large administrative implications for business then we would of course get a lot of questions if it is right to suggest those measures. So such suggestions have to very well-argued for if they are put forth (SBA chief economist - (14))

It has to be hard to introduce a ban. One has to be really certain that it has the desired effect (SBA

chief economist - (14))

I questioned the scientific backing [...] And the researchers agreed, so the current report does not include the idea to put 300 million SEK into something that is so uncertain (Industry representative (13))

It's a problem with cost efficiency. On many occasions we cannot quantify - we cannot say how many kilos or $\mathrm{CO} 2$-eqvivalents a measure would save. We can say if it probably is positive but no more. There is no model that can grasp how great the reduction will be. That is a difficult basis for suggesting policy (SBA investigator (2)).

When it comes to dairy production, Swedish Milk, which represents the dairy industry, works hard to reduce the usage of soy because however you calculate, this is the largest environmental problem with Swedish production. And it keeps popping up. It was in the press just now and it has kept coming back that using and importing soy is something that is not good and an environmental problem for Swedish production (Researcher (11)).

\section{Reluctance to}

introduce

regulation that may

challenge industry

interests
Preference for

policy that support

already existing

practice 
There have been very large expectations of the investigations that we have made, from the industry because they really, really hope that these grasslands store a lot [of carbon]. They are working uphill as the animals are portrayed as climate villains [...] We chose to include [the report's text on carbon storage] anyway in the practice change section, which might appear odd, but it is simply

because there are such enormous expectations

which would cause many questions if it was left out

(SBA investigator (3)).

[...] there are many [farmers] that think that this

Sympathy for

farmers

that we should not be producing any food because

we are only destroying the environment (Consultant (31)).

One thinks that sometimes media cry out that this is so much their [the farmers] fault (Consultant (33)).

Yes. It is about economy in the end. Unequivocally really. So it is about finding those opportunities for improvement, or point at what they are already doing, already are improving; what the climate impacts of those actions are (Consultant (30)).

We don't think that the farmer has any loftier goals than $[. .$.$] to develop his business (SBA chief$ economist (14)).

... and whether we should eat that many kilos of beef or drink that many liters of milk, which is not up to provision of advice and not really up to the farmer either, but in someway an issue for society at large (KB - consultant).
Responsibility of

consumers

\section{Farmers' legitimate}

concern is towards

their businesses

\author{
Shaping \\ responsibilities - \\ makes GHG reduction \\ the responsibility of \\ others
}


Swedish dairy production is really highly climate

efficient since our production per cow is so high

(KB - consultant)

I could turn it around and say that it's ok to increase the total emissions from Swedish agriculture

assuming that we forcefully increase our

production, and this is because we often have a

climate friendly production and it would benefit the

whole globe if we produced more food (ED -
Swedish and

foreign producers

consultant) 
In the Action Plan-report it is evident that no policy can survive without the support of the researchers at the advisory board, but when this support is aligned with the ideas suggested by the SBA-investigators, some rather expensive policies are suggested. This refers to trying to increase bioenergy production, where millions in investment supports are made available for the industry:

The bureau makes a preliminary suggestion to maintain or increase the current campaign with investment supports to manure based biogas [production] [...] This would mean putting up 75 million SEK per annum from 2014 onwards to biogas investments, making the total amount 225 million SEK for the period 2014-2016 (SBA, 2010, p. 31).

These policies do not directly challenge the legitimacy of agricultural practice, but are rather an attempt to create a new aspect of this practice, as farmers move away from producing food and instead produce bioenergy. Still, in the long run, if farmers find this more rewarding it may lead to a complete restructuring of agri-food practice.

Redefining practice. This last theme presupposes the themes described above, and amounts to an altered script, in the sense that it introduces a new and coherent understanding of agricultural practices' relations to climate change. It integrates the themes and realigns the cognitive disorder generated by the problematizations. It not only neutralizes the challenge to legitimacy but partly turns climate into something that the industry can use as an argument for practice. This script expands on the interpretation that agricultural emissions are unavoidable, and once this is accepted the preferred course of action is to produce as efficiently as possible, maximizing output relative to caused emissions:

[...] produce as much milk today as 20 years ago but with $20 \%$ less greenhouse gasemissions. This is where Swedish production comes out good. It is a consequence of having worked with the system's efficiency and productivity. That is the matter in which Swedish production holds its ground. The work with breeding and fodder analysis and such things. It has had the additional effect that we get relatively a lot of food per $\mathrm{CO}_{2} \mathrm{e}$ (SBA investigator (2)).

Thus by assembling a new script the cognitive order within the regulative pillar can be restored. Such a script is important as it enables the coordination of activities within the pillar, 
and also provide a heuristic for how the multitude of components of climate change as an issue, in this particular context, should be handled by policy workers. In short, this heuristic says that "efficient farming is climate-friendly farming", reducing much of the complexities that the issue seems to imply.

Obviously this script has pragmatic value, perhaps more so for certain respondents, for instance the consultants that need to visit farmers and talk to them about sensitive issues. But also for the policy investigators who are supposed to deal with a complex material and provide policy suggestions that could be both controversial and costly. And it is not a standalone script, but one that draws on wide-spread ideas regarding the virtue of efficiency.

Hence, although cognitive alignment is perhaps mostly discussed in connection with the cognitive pillar, it seems that shared scripts are as important to coordinate the institutional work within the regulative pillar. Thus our findings suggest that institutional maintenance takes two slightly different forms. For the sake of analytical clarity they are described as separate, although in reality they are overlapping and simultaneous: First there are seemingly creative acts of patching together a new script that simultaneously takes into account problematizations while neutralizing them. These acts are creative, and also reflective, in terms of drawing on multiple arguments and ideas to achieve this. Institutional workers display both skill in terms of knowing their particular subject matter, but also skill in the sense of being able to piece their argument together. Second, once the script is established, it enables maintenance by providing a base for decision about what policy to suggest, or how to advice farmers. In other words, the scripts enables activities tending towards maintenance, and is at the same time maintained itself by being consistently activated. It becomes fortified as it has pragmatic value for policy workers, it makes their everyday work easier. 


\section{DISCUSSION}

This paper has sought to explain how institutional maintenance occurs within the regulative pillar. While the institutional work-literature has provided explanations for the role of the normative and cognitive pillar in maintenance, a considerable gap remains concerning the regulative pillar. Some previous accounts of institutional maintenance rather start when regulatory change has already taken-place (Micelotta \& Washington, 2013; Rainelli et al., 2016), effectively black-boxing the institutional work within the regulative pillar. Our paper has suggested that two slightly different forms of maintenance exist, on the one hand the work that goes into enforcing policy, that is ensuring compliance, and on the other hand the work that goes into preserving supporting policies as such. And that the latter form better exemplifies that purposive and skillful work intended by the institutional work-concept (Lawrence, Suddaby, \& Leca, 2009). As mentioned, we find that a lot of this skill is directed at restoring cognitive scripts, while at the same time not denying problematizations. There are some reasons to believe that such patterns can also be found in maintenance work within regulative pillars in other functional and geographical contexts. First, state bureaucracies tend to herald impartial and rationalistic decision-making, suggesting that problematizations are seldom rejected out-of-hand, especially if they are based upon scientific reports. Thus problematization rather typically trigger institutional work to either adapt or preserve related policies. However, when implications of problematizations conflict with other important goals, they are likely to be skillfully moderated by policy workers:

Proposition 1: Problematizations trigger institutional work within the regulative pillar

Proposition 2: Maintenance within the regulative pillar involves neutralizing, but not rejecting, problematizations.

The rationalistic ideal makes for an approach to decision-making that is fraught with potential uncertainties, it is easy to for external actors to question any idea when it is confronted with 
the ideal of how rational decisions should be made (Brunsson, 2006). Given the potential wide-range consequences of policies, both in terms of financial and political costs, it is to be expected that policy workers are cautious rather than bold. Thus we propose that:

Proposition 3: The rationalistic approach to decision-making within the regulative pillar makes it easy to question ideas for new policy.

Second, arguably policy workers in most contexts are expected to work with multiple issues, and those that succeed at performing multiple tasks will likely prevail. For this reason, adapted scripts that both enable speedy decision-making and avoid critique from stakeholders are likely to evolve. For instance, in our case the consultants that had the most pro-farmer and reductionist approach to climate change were also the ones that did the most consulting. Those that were more critical and hesitant did not prevail.

Proposition 3: Scripts are needed in the regulative pillar because they simplify work.

Proposition 4: Problematizations trigger the need for assembling new scripts.

Thus, as argued, institutional maintenance in the regulative pillar contains two different dimensions, first it involves the skillful acts of assembling new scripts, and second the act of utilizing those scripts to preserve and defend policies supportive of practices.

Proposition 5: Once new scripts are assembled they are used to justify preserving policies that support practices.

To summarize, our analysis suggest that cognitive scripts are important for maintenance within the regulative pillar, possible pointing to the influences "between" pillars, and the somewhat arbitrary separation between different types of mechanisms. Clearly the factmaking of the scientific community affects policy making, both the facts about climate change that triggered maintenance work, but also, interestingly enough, the facts that support 
the views that moderate problematizations. The latter includes claims and statements based upon economics as a theory of how society works, but also many more "local" theories of Swedish agricultural science. Given the rationalistic nature of bureaucratic decision-making there are reasons to believe that facts and claims emanating from the cognitive pillar has an influence, both as a moderator and trigger, upon what happens in the regulative pillar:

Proposition 6: Facts and statements emanating from the cognitive pillar influences institutional work within the regulative pillar.

\section{CONCLUSIONS}

Even if political scientists have developed much understanding of policy making and the workings of what institutional theory refers to as the regulative pillar, this pillar and the work that goes into maintaining it not well understood among organizational scholars. This is a problem given the often decisive influence policies have on organizational practice, the practice within agricultural discussed here is but one example. The theory developed here suggests that the rationalistic mode of bureaucratic decision-making makes institutional work in the regulative pillar on the one hand distinct, but that it, on the other hand, is also highly influence by facts, statements and claims emanating from the cognitive pillar, in particular scientific fact-making processes.

\section{REFERENCES}

Ahmadjian, C. L., \& Robinson, P. 2001. Safety in numbers: Downsizing and the deinstitutionalization of permanent employment in Japan. Administrative Science 
Quarterly, 46(4): 622-654.

Battilana, J., Leca, B., \& Boxenbaum, E. 2009. How Actors Change Institutions: Towards a Theory of Institutional Entrepreneurship. The Academy of Management Annals, 3(1): 65-107.

Brunsson, N. 2006. Mechanisms of hope: Maintaining the dream of the rational organization. Copenhagen: Copenhagen Business School Press.

Campbell, J. L. 2007. Why Would Corporations Behave in Socially Responsible Ways? an Institutional Theory of Corporate Social Responsibility. Academy of Management Review, 32(3): 946-967.

Clegg, S. 2010. The State, Power, and Agency: Missing in Action in Institutional Theory? Journal of Management Inquiry, 19(1): 4-13.

Currie, G., Lockett, A., Finn, R., Martin, G., \& Waring, J. 2012. Institutional work to maintain professional power : recreating the model of medical professionalism. Organization Studies, 33(7): 937-962.

Dacin, M. T., Munir, K., \& Tracey, P. 2010. Formal Dining at Cambridge Colleges: Linking Ritual Performance and Institutional Maintenance. Academy of Management Journal, 53(6): 1393-1418.

DiMaggio, P., \& Powell, W. 1983. The iron cage revisited: Institutional isomorphism and collective rationality in organizational fields. American Sociological Review, 48(2): $147-160$

Eisenhardt, K., \& Graebner, M. 2007. Theory building from cases: opportunities and challenges. Academy of Management Journal, 50(1), 25-32.

Emirbayer, M., \& Mische, A. 1998. What is agency? American Journal of Sociology, 103(4): 
$962-1023$.

Garud, R., Hardy, C., \& Maguire, S. 2007. Institutional Entrepreneurship as Embedded Agency: An Introduction to the Special Issue. Organization Studies, 28(7): 957-969.

Gawer, A., \& Phillips, N. 2013. Institutional Work as Logics Shift: The Case of Intel's Transformation to Platform Leader. Organization Studies, 34(8): 1035-1071.

Greenwood, R., \& Suddaby, R. 2006. Institutional Entrepreneurship in Mature Fields: The Big Five Accounting Firms. Academy of Management Journal, 49(1): 27-48.

Hardy, C., \& Maguire, S. 2008. Institutional entrepreneurship. In Greenwood, R., Oliver, C., Suddaby, R., \& Sahlin-Andersson, K. (Eds.), The Sage handbook of organizational institutionalism: 198-217. London: Sage

Harmon, D. J., Green, S. E., \& Goodnight, G. T. 2015. A Model of Rhetorical Legitimation : the Structure of Communication and Cognition Underlying Institutional Maintenance and Change. Academy of Management Review, 40(1): 76-95.

Heclo, H. H. 1972. Review article: Policy analysis. British Journal of Political Science. 2(01): 83-108.

Hoffman, A. 1999. Institutional evolution and change: Environmentalism and the US chemical industry. Academy of Management Journal, 42(4): 351-371.

Hoggan, J., Littlemore, R. D., \& Ball, T. 2009. Climate cover-up: The crusade to deny global warming. Vancouver: Greystone books.

Holm, P. 1995. The Dynamics of Institutionalization: Transformation Processes in Norwegian Fisheries. Administrative Science Quarterly, 40(3): 398-422.

Jepperson, R. L. 1991. Institutions, institutional effects, and institutionalism. The New 
Institutionalism in Organizational Analysis, 6: 143-163.

Jiao, W., \& Boons, F. 2013. Toward a research agenda for policy intervention and facilitation to enhance industrial symbiosis based on a comprehensive literature review. Journal of Cleaner Production, 67: 14-25.

Jordan, A., Wurzel, R. K. W., \& Zito, A. R. 2013. Still the century of "new" environmental policy instruments? Exploring patterns of innovation and continuity. Environmental Politics, 22(1): 155-173.

Jordan, A., Wurzel, R., \& Zito, A. 2003. "New”instruments of environmental governance: Patterns and pathways of change, Environmental Politics, 12(1): 1-24.

Lawrence, T. B., Suddaby, R., \& Leca, B. 2009. Institutional work: Actors and agency in institutional studies of organizations. Cambridge: Cambridge University Press.

Lawrence, T., \& Suddaby, R. 2006. 1.6 Institutions and Institutional Work. In Clegg, S. R., Hardy, C., \& Nord, W. R. Handbook of organization studies: 215-243 London: SAGE Publications Ltd.

Lawrence, T., Suddaby, R., \& Leca, B. 2011. Institutional Work: Refocusing Institutional Studies of Organization . Journal of Management Inquiry , 20(1): 52-58.

Lefsrud, L. M., \& Meyer, R. E. 2012. Science or Science Fiction? Professionals' Discursive Construction of Climate Change. Organization Studies, 33(11): 1477-1506.

Levy, D., \& Egan, D. 2003. A Neo-Gramscian Approach to Corporate Political Strategy: Conflict and Accommodation in the Climate Change Negotiations*. Journal of Management Studies, 40(4): 803-829.

Lok, J., \& Rond, M. De. 2012. On the plasticity of institutions: Containing and restoring practice breakdowns at the Cambridge University Boat Club. Academy of Management 
Journal, 56(1): 185-207.

Lounsbury, M., \& Crumley, E. T. 2007. New Practice Creation: An Institutional Perspective on Innovation. Organization Studies, 28(7): 993-1012.

Maguire, S., \& Hardy, C. 2009. Discourse and Deinstitutionalization: the Decline of DDT. Academy of Management Journal, 52(1): 148-178.

Meyer, J., \& Rowan, B. 1977. Institutionalized organizations: Formal structure as myth and ceremony. American Journal of Sociology, 83(2): 340-363.

Micelotta, E. R., \& Washington, M. 2013. Institutions and Maintenance: The Repair Work of Italian Professions. Organization Studies, 34(8): 1137-1170.

Mol, A., \& Sonnenfeld, D. 2000. Ecological modernisation around the world: an introduction. Environmental Politics, 9(1): 1-14.

Okereke, C. 2007. An Exploration of Motivations, Drivers and Barriers to Carbon Management:. The UK FTSE 100. European Management Journal, 25(6), 475-486.

Oreskes, N. 2004. The scientific consensus on climate change. Science, 306(5702): 16861686.

Oreskes, N., \& Conway, E. M. 2010. Merchants of doubt: how a handful of scientists obscured the truth on issues from tobacco smoke to global warming. USA: Bloomsbury Publishing.

Peton, H., \& Pezé, S. 2014. The unsuspected dynamics of the regulative pillar: The case of Faute inexcusable in France. Management, 17(3): 145-179.

Rainelli Weiss, H., \& Huault, I. 2016. Business as Usual in Financial Markets? The creation of incommensurables as institutional maintenance work. Organization Studies. 
0170840615626463.

Reay, T., \& Hinings, C. R. 2009. Managing the Rivalry of Competing Institutional Logics. Organization Studies, 30(6): 629-652.

Scott, W. R. 2001. Institutions and organizations. Thousand Oaks: Sage.

Scott, W. R. 2008. Institutions and Organizations: Ideas and Interests. Thousand Oaks: Sage.

Scott, W. R. 2008. Lords of the Dance: Professionals as Institutional Agents. Organization Studies, 29(2): 219-238.

Siggelkow, N. 2007. Persuasion With Case Studies. Academy of Management Journal, 50(1): 20-24.

Wittneben, B. B. F., Okereke, C., Banerjee, S. B., \& Levy, D. L. 2012. Climate Change and the Emergence of New Organizational Landscapes. Organization Studies, 33(11): 14311450.

Zietsma, C., \& Lawrence, T. B. 2010. Institutional Work in the Transformation of an Organizational Field: The Interplay of Boundary Work and Practice Work. Administrative Science Quarterly, 55(2): 189-221. 